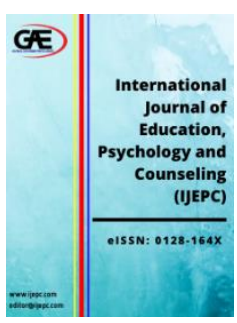

\author{
INTERNATIONAL JOURNAL OF \\ EDUCATION, PSYCHOLOGY \\ AND COUNSELLING \\ (IJEPC) \\ www.ijepc.com
}

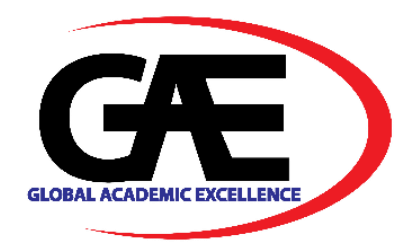

\title{
READING DIFFICULTIES AMONG MALAYSIAN UNDERGRADUATE ESL LEARNERS: A PRELIMINARY STUDY
}

\author{
Eugenia Ida Edward ${ }^{1 *}$, Kamsilawati Kamlun ${ }^{2 *}$, Wardatul Akmam Din ${ }^{3}$, Chelster Sherralyn Jeoffrey \\ Pudin $^{4}$
}

1 Centre for the Promotion of Knowledge and Language Learning, Universiti Malaysia Sabah, Malaysia

Email: eugenia.ida@ums.edu.my

2 Centre for the Promotion of Knowledge and Language Learning, Universiti Malaysia Sabah, Malaysia

Email: kamsi@ums.edu.my

$3 \quad$ Faculty of Psychology and Education, Universiti Malaysia Sabah, Malaysia

Email: wardadin@ums.edu.my

4 Centre for the Promotion of Knowledge and Language Learning, Universiti Malaysia Sabah, Malaysia

Email: chelster@ums.edu.my

* Corresponding Author

\section{Article Info:}

\section{Article history:}

Received date: 11.09.2021

Revised date: 10.10 .2021

Accepted date: 15.11.2021

Published date: 30.11.2021

\section{To cite this document:}

Edward, E. I., Kamlun, K., Din, W. A., Pudin, C. S. J. (2021). Reading Difficulties Among Malaysian Undergraduate ESL Learners: A Preliminary Study. International Journal of Education, Psychology and Counseling, 6 (43), 62-70.

DOI: $10.35631 /$ IJEPC.643006

This work is licensed under CC BY 4.0

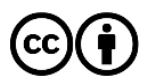

\begin{abstract}
:
Reading deficiency in reading English texts or materials among ESL undergraduate students has been one of the most significant problems in Malaysia. Educators in Malaysia are currently facing the problem as it reflects on their students' academic performance. This study aims to investigate Malaysian ESL undergraduate students' reading difficulties in reading English texts. 25 Malaysian students who are taking advanced English courses in a university, were selected to participate in this study. A quantitative method was employed for this study. The questionnaires were designed to fit the purpose of this study. Data analysis was done using SPSS to analyse the data collected. The result shows that students are weak in grasping the main idea when they are reading, having poor vocabulary, lack of reading habit and interest in reading English texts, and are pressured with the lack of time when reading. It can be concluded that reading deficiency affects their academic performance and their English proficiency. In overcoming their difficulties, students must equip themselves with some reading strategies to help them to comprehend the English texts that they are reading.
\end{abstract}

Keywords:

English Reading, ESL, Reading Difficulties, Comprehension, Strategies 


\section{Introduction}

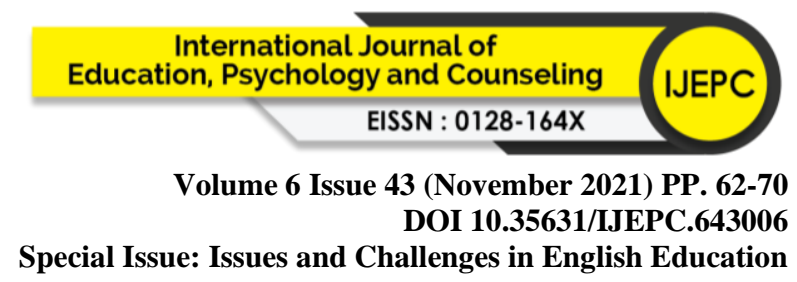

Reading is an essential language ability that should never be overlooked. It is one of the most important ways to receive knowledge, particularly for educational purposes. Reading is one of the most widely used language competency skills all around the world. Furthermore, students' academic performance suffers because of their inability to read. They also confront a variety of issues outside of the classroom as a result of their reading difficulties (Mundhe, 2015).

Learners who do not comprehend the material will not be able to appreciate it. In addition, a lack of linguistic expertise may result in a loss of understanding. This implies a substantial link between reading comprehension and word knowledge. As a result, in order to interpret literature, ESL learners must have a significant vocabulary. ESL learners who have developed a dislike for the foreign language find it difficult to understand reading materials written in the language. Prior knowledge (schemata) can also help learners understand and construct meaning from reading content (Nozen et al., 2017; Vacca, 2002). ESL learners who are unable to connect their prior knowledge and predict the text's likely meaning may struggle to comprehend the material in this regard. It's possible that this is due to a lack of knowledge of English etymology. One of the most evident challenges teachers face today, according to Nezami (2012), is a lack of reading comprehension among students in higher education institutions. As a result of this impairment, their academic performance may suffer.

This study intends to investigate reading difficulties among ESL learners, particularly undergraduate Malaysian students in higher education, based on the situation mentioned. The study is expected to produce reliable results that will aid in the understanding of the problem and the development of viable solutions.

\section{Literature Review}

Many studies looked into the reading problems of students. Chawwang (2008) investigated EFL learners' English reading difficulties. The majority of students struggled to understand English literature, according to the data. A lack of word knowledge was noted as one of the primary difficulties (Gunning, 2002). Complicated reading materials, such as textbooks, necessitate a large vocabulary, especially those incorporating technical terms (Carlisle, 2000; Qian, 2002). This is due to the fact that youngsters with a restricted vocabulary have difficulty understanding technical concepts such as superordinate, synonyms, antonyms, and words with many connotations (Nuttall, 2000; Carlisle, 2000; VileniusTuohimaa, Aunola, \& Nurmi, 2008).

Exposure to the text structure and attentiveness are two other characteristics that influence reading comprehension abilities (Perfetti, Landi, \& Oakhill, 2004; Meniado, 2016). According to Davoudi and Yousefi, environmental, educational, and biological factors all have a role in many children' reading difficulties (2015). According to the author, pupils who struggle with reading have comprehension issues for a variety of reasons, and some of these issues may be linked to imprecise or inadequate word identification and decoding skills. The children' reading comprehension is influenced by their surroundings. In a tumultuous setting, they may struggle to comprehend reading information. Those who read in a peaceful and regulated environment, on the other hand, may be more effective readers. Students that are stressed have a difficult time concentrating on their academics. However, when students are in a safe atmosphere, their reading skills become more efficient. It has been proved that in a 


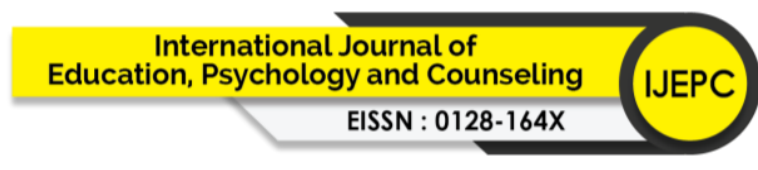

Volume 6 Issue 43 (November 2021) PP. 62-70

DOI 10.35631/IJEPC.643006

Special Issue: Issues and Challenges in English Education noisy atmosphere, such as one with a lot of televisions or radios, students lose focus on reading and understanding (Dennis, 2008).

Working memory has an impact on reading skills. This suggests that human memory plays an important role in text comprehension. It assists kids to better absorb literature (Kintsch \& Kintsch, 2005; Chrysochoou, Bablekou, \& Tsigilis, 2011; Nouwens, Groen, \& Verhoeven, 2017). Anxiety, according to Vazalwar (2011), has a deleterious impact on reading comprehension. In the study, anxiety was revealed to be negatively related to students' reading abilities. This means that a moderate level of anxiety has a positive effect on reading ability. In reality, anxiety is a fear-based feeling that impairs one's ability to read. Other research (Wu, 2011; Jafarigohar \& Behrooznia, 2012) has discovered a link between anxiety and reading ability. According to Grills-Taquechel et al. (2012), stressful thoughts such as panic and behaviours such as shaking hands might cause learners' academic performance to decline. When reading English literature, homework, classwork, and exam situations all lead to anxiety. Students are compelled to read for reasons other than pleasure in these conditions. Certain kids thrive in these situations, while others are overwhelmed by the reading strain. As a result, students who struggle with reading are more likely to suffer anxiety (Dennis, 2008).

According to Kim \& Anderson (2011), reading is widely recognised as a means of gaining new knowledge and information. It is not only to acquire information, but also to develop maturity and a broader understanding of current concerns. A good reading habit is essential for the growth of personalities and mental abilities. This habit is essential for a person's intellectual development and plays a critical part in achieving language proficiency (Grabe \& Stoller, 1997). Furthermore, an individual's desire to read is determined by the volume and intensity with which he or she pursues the reading activity (Cleary, 1972). Cunningham \& Stanovich (2001) mentioned reading books on a regular basis and developing a strong reading habit allows the reader to analyse other people's ideas, allowing them to think more critically. Reading supplies readers with a wealth of information, comprehension, and a feeling of values, allowing them to progressively build the greatest of all virtues: the ability to understand the beliefs of others (Cook, Halleran, \& O'Brien, 1998).

Individuals' feelings for reading are characterised as their attitudes toward reading. It leads to students adopting or avoiding a reading scenario (Alexander \& Filler, 1976). Feelings and their willingness to read are linked to their attitude and interest in reading. McKenna, Kear, and Ellsworth (1996) define reading attitude as a set of feelings about reading that causes a learner to approach or avoid a reading scenario.

\section{Methodology}

This study uses a quantitative approach, with data collected from 25 Malaysian ESL students at a public institution using test methodologies. The difficulties faced by Malaysian ESL learners are investigated using test data as numerical data in this study. A test of 15 questions was created to assess reading difficulties in general. The questions were changed to be more in line with the study's research goal. The overall goal of this research is to look into the reading challenges of ESL students at a public university. 


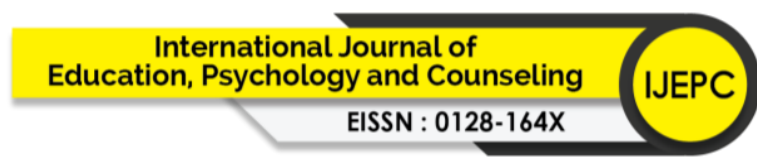

Volume 6 Issue 43 (November 2021) PP. 62-70

DOI 10.35631/IJEPC.643006

Special Issue: Issues and Challenges in English Education

Twenty-five Malaysian ESL students from a public institution were chosen to reply to the questions. The pupils were chosen because they were enrolled in a reading proficiency course. The participants in this study were chosen using probability sampling, which employs basic random sampling. The ESL students are chosen at random by the researcher, and the test is given to any student within reach. Each member of the population under investigation has an equal chance of being chosen in simple random sampling, and the likelihood of being chosen is unaffected by the selection of other members of the population. Malaysian ESL undergraduate students from various faculties at a public university make up the population in the quantitative phase of this study.

The quantitative data was compiled, tabulated, and analysed using SPSS. To acquire information on students' obstacles in reading English literature, the frequencies and means of all elements were calculated.

\section{Result and Discussion}

The purpose of this study is to look into the challenges that Malaysian ESL students have in comprehending English texts or materials. There are various factors to consider while determining the causes of ESL students' reading difficulty. Comprehension, vocabulary, methods, interest, and pressure are some of these factors. The results linked to the problems faced by Malaysian ESL learners in their reading difficulties, notably at public universities in Malaysia, are presented in the following figures.

Table 1: Reading Comprehension Faced By ESL Learners

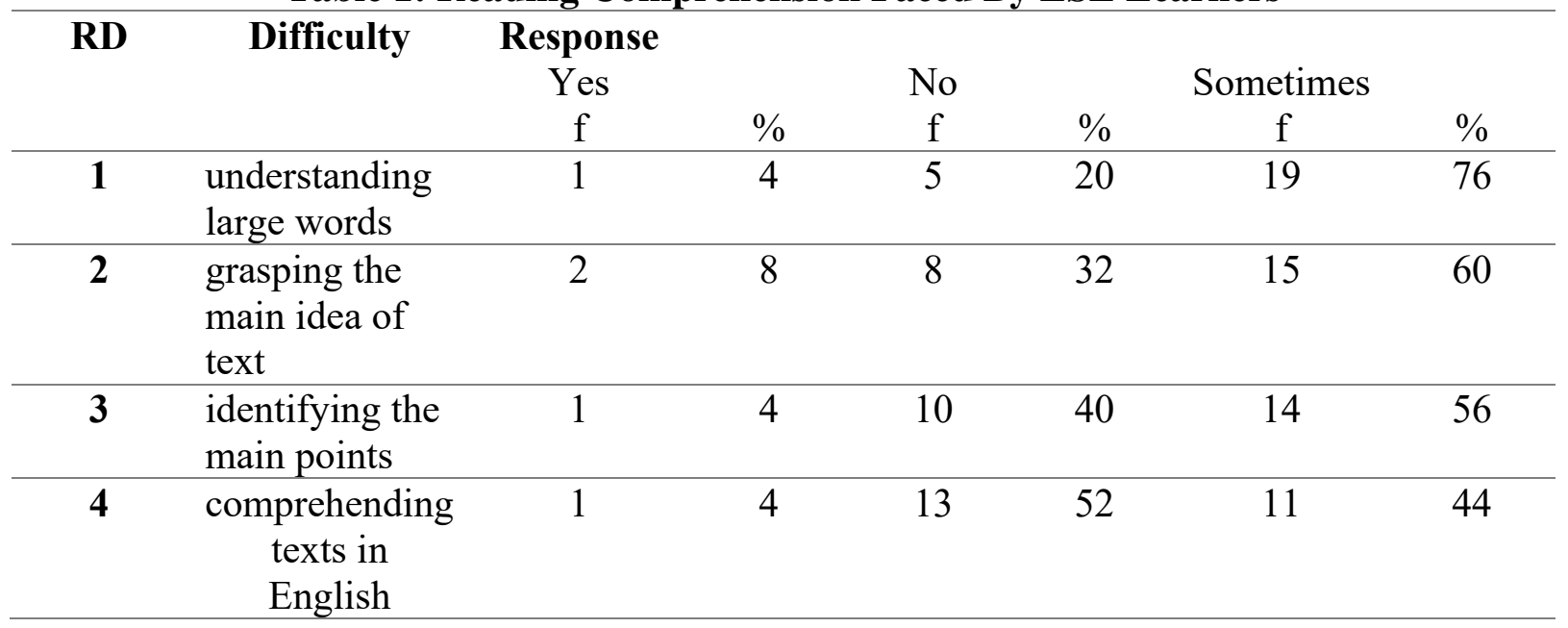

Table 1 shows that 76 percent of respondents have troubled understanding large words on sometimes. Only $4 \%$ of respondents admitted to having problems understanding large words, whereas $20 \%$ of respondents said they had no difficulty understanding large words. Furthermore, $60 \%$ of respondents had difficulty grasping the main point of the text at times. 32 percent of respondents say they have no trouble absorbing the main idea of a text, while $8 \%$ say they have difficulty doing so while reading English literature. When reading English literature, 56 percent of respondents had trouble identifying the major points at times, whereas 40 percent have no trouble identifying the main ideas. Only $4 \%$ of respondents feel that identifying the major ideas is a difficult task. When reading, a large percentage of the respondents $(52 \%)$ appear to have no trouble understanding English texts. $44 \%$ of Copyright $\odot$ GLOBAL ACADEMIC EXCELLENCE (M) SDN BHD - All rights reserved 


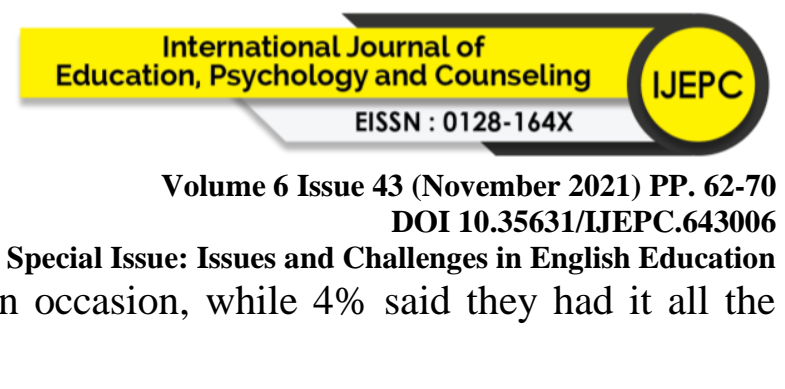

Table 2: Vocabulary Problems Faced By ESL Learners

\begin{tabular}{clcccccc}
\hline RD & Difficulty & $\begin{array}{c}\text { Response } \\
\text { Yes }\end{array}$ & f & $\%$ & No & \multicolumn{3}{c}{ Sometimes } & \\
\hline $\mathbf{1}$ & $\begin{array}{l}\text { forget some } \\
\text { vocabulary }\end{array}$ & 5 & 20 & 2 & 8 & 18 & 72 \\
& learnt & & & & & & \\
\hline $\mathbf{2}$ & $\begin{array}{l}\text { have poor } \\
\text { vocabulary }\end{array}$ & 8 & 32 & 4 & 16 & 13 & 52 \\
\hline
\end{tabular}

Table 2 indicates that 72 percent of the respondents had forgotten some of the vocabulary they had learned at some point. $20 \%$ of respondents recognise that they have forgotten some vocabulary and $8 \%$ don't lose the learned vocabulary. In total, $32 \%$ of students reported that they had a limited vocabulary that caused them to poorly read the English text. As indicated by Carlisle (2000) and Qian (2002), reading resources like textbooks demand a strong vocabulary. ESL students have to comprehend many technical jargons or terminology because they may have limited vocabulary in order to understand the content they read (Nuttall, 2000; Carlisle, 2000; VileniusTuohimaa, Aunola, \& Nurmi, 2008). Learning to read well necessitates the development of strong vocabulary skills (Taylor et al., 2009).

Table 3: Reading Strategies Used By ESL Learners

\begin{tabular}{|c|c|c|c|c|c|c|c|}
\hline \multirow[t]{3}{*}{ RD } & \multirow[t]{3}{*}{ Difficulty } & \multirow{3}{*}{$\begin{array}{c}\text { Response } \\
\text { Yes } \\
\text { f }\end{array}$} & \multirow{2}{*}{\multicolumn{2}{|c|}{ No }} & \multirow{2}{*}{\multicolumn{2}{|c|}{ Sometimes }} & \multirow[b]{3}{*}{$\%$} \\
\hline & & & & & & & \\
\hline & & & $\%$ & $\mathrm{f}$ & $\%$ & $\mathrm{f}$ & \\
\hline 1 & $\begin{array}{l}\text { use title or } \\
\text { pictures as } \\
\text { part of story } \\
\text { orientation }\end{array}$ & 11 & 44 & 3 & 12 & 11 & 44 \\
\hline 2 & $\begin{array}{l}\text { use prior } \\
\text { knowlegde in } \\
\text { reading new } \\
\text { texts }\end{array}$ & 12 & 48 & 2 & 8 & 11 & 44 \\
\hline 3 & $\begin{array}{l}\text { elaborate, } \\
\text { infer, predict } \\
\text { or summarize } \\
\text { while reading }\end{array}$ & 13 & 52 & 6 & 24 & 6 & 24 \\
\hline 4 & $\begin{array}{l}\text { read slowly to } \\
\text { understand a } \\
\text { text }\end{array}$ & 7 & 28 & 5 & 20 & 13 & 52 \\
\hline 5 & $\begin{array}{l}\text { reread to } \\
\text { make sense }\end{array}$ & 21 & 84 & 0 & 0 & 4 & 16 \\
\hline
\end{tabular}




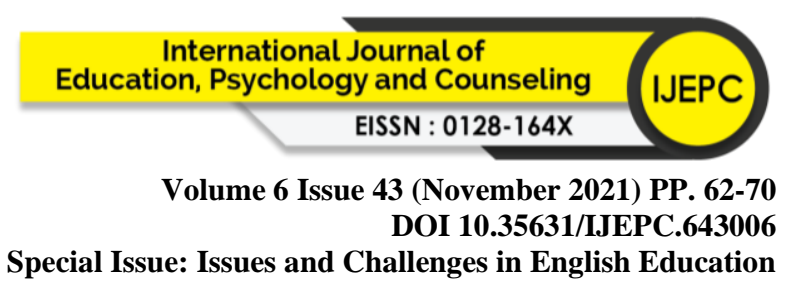

The consciousness or knowledge of ESL learners employing reading methods to grasp English texts reading is depicted in Table 3 . While reading, the majority of students reread to grasp the texts ( 84 percent), followed by predicting, summarising, elaborating, and inferring (52 percent ). In order to comprehend the English content they are reading, ESL students need certain basic tactics. As a conclusion, conscious readers can recognise which methods are acceptable or improper for various reading settings, and they can watch their reading, which helps them improve their comprehension of what they read (Paris, Lipson, \& Wixson, 1983).

Table 4 Reading Interest By ESL Learners

\begin{tabular}{|c|c|c|c|c|c|c|c|}
\hline \multirow[t]{2}{*}{ RD } & \multirow[t]{2}{*}{ Difficulty } & \multirow{2}{*}{$\begin{array}{c}\text { Response } \\
\text { Yes } \\
\text { f }\end{array}$} & \multicolumn{3}{|c|}{ No } & Sometimes & \multirow[b]{2}{*}{$\%$} \\
\hline & & & $\%$ & $\mathrm{f}$ & $\%$ & f & \\
\hline 1 & $\begin{array}{l}\text { lack of } \\
\text { reading habit } \\
\text { can cause } \\
\text { reading } \\
\text { difficulties }\end{array}$ & 23 & 92 & 1 & 4 & 1 & 4 \\
\hline 2 & $\begin{array}{l}\text { lack of } \\
\text { interest in } \\
\text { reading can } \\
\text { cause reading } \\
\text { difficulties }\end{array}$ & 23 & 92 & 2 & 8 & 0 & 0 \\
\hline
\end{tabular}

Table 4 shows how vital it is for ESL students to enjoy reading in order to enhance their English reading skills. Reading difficulties might be caused by a lack of reading habit and interest, according to the majority of students ( 92 percent). $4 \%$ and $8 \%$, on the other hand, do not believe that your reading ability is affected by your interest. Reading materials written in English is tough and causes learners to lose interest in reading (Annamalai \& Balakrishnan, 2013). Aside from that, students believe that reading is tedious and unmotivating.

Table 5 Reading pressure by ESL learners

\begin{tabular}{|c|c|c|c|c|c|c|c|}
\hline \multirow{3}{*}{ RD } & \multirow{3}{*}{ Difficulty } & \multirow{3}{*}{$\begin{array}{c}\text { Response } \\
\text { Yes } \\
\text { f }\end{array}$} & \multirow{2}{*}{\multicolumn{2}{|c|}{ No }} & & \multirow[b]{2}{*}{ Sometimes } & \multirow[b]{3}{*}{$\%$} \\
\hline & & & & & & & \\
\hline & & & $\%$ & $\mathrm{f}$ & $\%$ & $\mathrm{f}$ & \\
\hline 1 & $\begin{array}{l}\text { reading large } \\
\text { piece of text }\end{array}$ & 5 & 20 & 14 & 56 & 6 & 24 \\
\hline 2 & lack of time & 16 & 64 & 2 & 8 & 7 & 28 \\
\hline
\end{tabular}

Table 5 depicts the strain that ESL students face when reading English language literature. Insufficient time spent reading English texts is the biggest contributing to their reading difficulty, according to $64 \%$ of respondents. This demonstrates that students may experience reading anxiety because of the pressure to read English materials, particularly while facing exams or assignments (Dennis, 2008). Only $8 \%$ of respondents said they do not believe their reading issues are caused by a lack of time. The majority of ESL students ( 56 percent) do not believe that reading big amounts of text has an impact on their ability to read. With 24 percent and 28 percent feeling pressured to read big amounts of text and a lack of time, their 


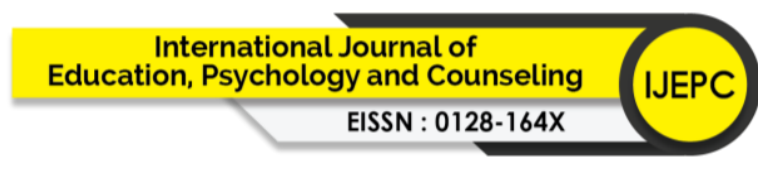

Volume 6 Issue 43 (November 2021) PP. 62-70

DOI 10.35631/IJEPC.643006

Special Issue: Issues and Challenges in English Education

reading ability was hampered. According to Vazalwar (2011), students' reading comprehension is negatively associated with their levels of anxiety.

The objective of this study is to identify reading difficulties faced by ESL learners. It was found that the major difficulty by Malaysian ESL learners examined in this study are grasping the main idea when they are reading, having poor vocabulary, lack of reading habit and interest in reading English texts and pressure with the lack of time when reading.

\section{Conclusion}

The reading problems items used in this study were meant to investigate the difficulties that ESL students faced when reading English texts. It is obvious that ESL students have a range of reading difficulties when reading English literature. The quantitative component of this study shows that grasping the main idea when they are reading, having poor vocabulary, lack of reading habit and interest in reading English texts and pressure with the lack of time when reading are the key challenges experienced by Malaysian ESL students. Respondents absorb reading materials through various reading strategies, and the majority of them reread to understand what they've read. Students must empower themselves with reading strategies to help them comprehend the English language in order to overcome these challenges. The findings will broaden the teacher's perspective on how to teach reading in the classroom. It also aids learners in developing awareness of strategy use in overcoming reading obstacles, and it enables them to enjoy reading and gain a better understanding if they employ the proper technique. The effectiveness of reading strategy can increase language instructors' use of language and learners' correct implication.

There are several flaws in the way this study was conducted. The tiny sample size, as well as the modest number of students that responded to the surveys, are among them. For more trustworthy results, a larger scale study with the addition of more variables such as family background, reading exposure, and availability of reading materials, as well as variables connected especially to reading in the digital environment, is required. Future research should concentrate on how reading may be done on computers and wireless communication devices, how non-linear reading extracts information and knowledge, and the elements that influence the on-line reading pattern.

\section{References}

Al-Jarrah, H., \& Ismail, N. S. B. (2018). Reading Comprehension Difficulties Among EFL Learners in Higher Learning Institutions. International Journal of English Linguistics, $32-41$.

Alexander, J. E., \& Filler, R. (1976). Attitudes and Reading. Newark, DE: International Reading Association.

Annamalai, S., \& Balakrishnan, M. (2013). Reading Habit and Attitude among Malaysian Polytechnic Students. International Online Journal of Educational Sciences, 5(1), 3241.

Carlisle, J. F. (2000). Awareness of the structure and meaning of morphologically complex words: Impact on reading. Reading and writing, 12(3), 169-190. https://doi.org/10.1023/A:1008131926604

Chawwang, N. (2008). An Investigation of English Reading Problems of Thai 12 th-Grade Students in Nakhonratchasima Educational Regions 1, 2, 3, and 7 (Doctoral dissertation). Srinakharinwirot University, Thailand.

Copyright $\odot$ GLOBAL ACADEMIC EXCELLENCE (M) SDN BHD - All rights reserved 


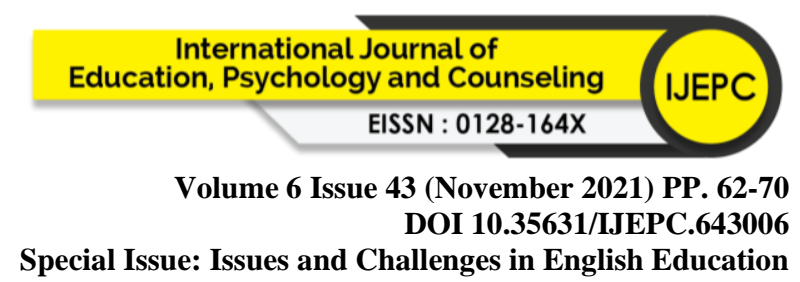

Chrysochoou, E., Bablekou, Z., \& Tsigilis, N. (2011). Working memory contributions to reading comprehension components in middle childhood children. The American journal of psychology, 124(3), 275-289. https://doi.org/10.5406/amerjpsyc.124.3.0275

Cleary, F. D. (1972). Blueprints for better reading: School programs for promoting skill and interest in reading (2nd ed.). New York, NY: Wilson Co.

Cohen, L., Lawrence, M., \& Keith, M. (2007). Research methods in education. New York: Routledge. https://doi.org/10.4324/9780203029053

Cook, A. E., Halleran, J. G., \& O'Brien, E. J. (1998). What is readily available during reading?: A memory based view of text processing. Discourse Processes Journal (Special Issue): Memory-Based Text Processing, 26 (2 \& 3), 109-129.

Cunningham, A. E., \& Stanovich, K. E. (2001). What Reading Does for the Mind. Journal of Direct Instruction, 1 (2), 137-149.

Davoudi, M., \&Yousefi, D. (2015). Comprehension Breakdown: A Review of Research on EFL Learners' Reading Difficulty and Problems. All rights reserved, 58(1), 22-31.

Dennis, D. V. (2008). Are Assessment Data Really Driving Middle School Reading Instruction? What we can learn from one student's experience. Journal of Adolescent and Adult Literacy, 51(7), 578-587. https://doi.org/10.1598/JAAL.51.7.5

Grabe, W., \& Stoller, F.L. (1997). Reading and Vocabulary Development in a Second Language: A case study. In Coady, J., and Huckin, T. N. (Eds.), Second Language Vocabulary Acquisition: A Rationale for Pedagogy (pp. 98 -122). USA: Cambridge University Press.

Grills-Taquechel, A. E., Fletcher, J. M., Vaughn, S. R., \& Stuebing, K. K. (2012). Anxiety and reading difficulties in early elementary school: Evidence for unidirectional-or bidirectional relations?. Child Psychiatry \& Human Development, 43(1), 35-47. https://doi.org/10.1007/s10578-011-0246-1

Gunning, T. G. (2002). Assessing and correcting reading and writing difficulties. Boston: Division of Simon \& Schuster, Inc.

Jafarigohar, M., \& Behrooznia, S. (2012). The effect of anxiety on reading comprehension among distance EFL learners. International Education Studies, 5(2), 159-174. https://doi.org/10.5539/ies.v5n2p159

Kim, J. Y., \& Anderson, T. (2011). Reading across the curriculum: A framework for improving the reading abilities and habits of college students. Journal of College Literacy and Learning, 37, 29-40.

Kintsch, W., \& Kintsch, E. (2005). Comprehension. In S. Paris \& S. Stahl (Eds.), Children's Reading Comprehension and Assessment (pp. 71-92). Mahwah, NJ: Lawrence Erlbaum Associates.

Leedy, P. D. (1993). Practical research: planning and design. New Jersey: Prentice-Hall.

McKenna, M.C., Kear, D.J., \& Ellsworth, R.A. (1996). Children's attitudes toward reading: A national survey. Reading Research Quarterly, 30 (4), 934-955.

Meniado, J. C. (2016). Metacognitive Reading Strategies, Motivation, and Reading Comprehension Performance of Saudi EFL Students. English Language Teaching, 9(3), 117-129. https://doi.org/10.5539/elt.v9n3p117

Mokhtari, K., \& Sheorey, R. (1994). Reading Habits of University ESL Students at Different Levels of English Proficiency \& Education. Journal of Research in Reading, 17(1), 46 -61 .

Mundhe, G. B. (2015). Teaching Receptive and Productive Language Skills the Help of Techniques. Pune Research an International Journal in English, 1(2), 1-6. 


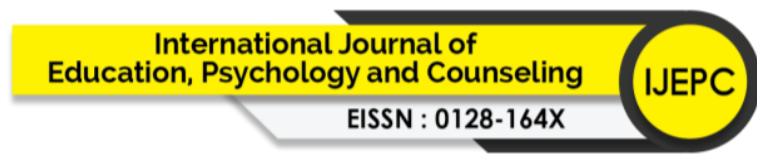

Volume 6 Issue 43 (November 2021) PP. 62-70

DOI 10.35631/IJEPC.643006

Special Issue: Issues and Challenges in English Education

Nezami, S. A. (2012). A critical study of comprehension strategies and general problems in reading skill faced by Arab EFL learners with special reference to Najran University in Saudi Arabia. International Journal Social Science and Education, 2(3), 306-316.

Nordin, N. M., Sabariah Md. Rashid, Sharifah Intan Safina Syed Zubir, \& Roslan Sadjirin. (2013). Differences in reading strategies: how esl learners really read. Procedia Social and Behavioral Sciences(90), 468-477.

Nouwens, S., Groen, M. A., \& Verhoeven, L. (2017). How working memory relates to children's reading comprehension: the importance of domain-specificity in storage and processing. Reading and Writing, 30(1), 105-120. https://doi.org/10.1007/s11145016-9665-5

Nozen, S. Z., Kalajahi, S. A. R., Abdullah, A. N., \& Jabbarzadeh, H. (2017). An investigation of the impacts of teaching writing skill through extensive short story reading. Journal of Nusantara Studies, 2(1), 53-70. https://doi.org/10.24200/jonus.vol2iss1pp53-70

Nuttall, C. (2000). Teaching reading skills in a foreign language. Oxford: Macmillan.

Pandian, A. (1997). Literacy in Postcolonial Malaysia. Journal of Adolescent \& Adult Literacy, 440 (5), 402-405.

Pandian, A. (2000, July). A study on readership behavior among multi-ethnic, multi-lingual Malaysian students. Paper presented at the 7th International Literacy and Education Research Network (LERN) Conference on Learning, RMIT University, Melbourne.

Paris, S., Lipson, M, \& Wixson, K. (1983). Becoming a strategic reader. Contemporary Educational Psychology, 8, 293-316.

Perfetti, C. A., Landi, N., \& Oakhill, J. (2004). The Acquisition of Reading Comprehension Skill.

Retrieved from:http://www.pitt.edu/ perfetti/PDF/The\%20Acquisition\%20of\%20Reading\%20C omprehension\%20Skill.pdf

Qian, D. D. (2002). Investigating the relationship between vocabulary knowledge and academic reading performance: An assessment perspective. Language learning, 52(3), 513-536. https://doi.org/10.1111/1467-9922.00193

Vazalwar, C. H. (2011). Effect of Anxiety on Reading Comprehension in English. International Journal of Multidisciplinary Research, 1(7), 272-278.

Vilenius-Tuohimaa, P. M., Aunola, K., \& Nurmi, J. E. (2008). The association between mathematical word problems and reading comprehension. Educational Psychology, 28(4), 409-426. https://doi.org/10.1080/01443410701708228

Wildemuth, B. M. (Ed.). (2016). Applications of social research methods to questions in information and library science. California: ABC-CLIO.

Yulia E., Mukhaiyar. (2021). Exploring the Reading Strategies Used by Male and Female Students. Advances in Social Science, Education and Humanities Research, 309-312. 